

\section{DISCLAIMER}

This report was prepared as an account of work sponsored by an agency of the United States Government. Neither the United States Government nor any agency Thereof, nor any of their employees, makes any warranty, express or implied, or assumes any legal liability or responsibility for the accuracy, completeness, or usefulness of any information, apparatus, product, or process disclosed, or represents that its use would not infringe privately owned rights. Reference herein to any specific commercial product, process, or service by trade name, trademark, manufacturer, or otherwise does not necessarily constitute or imply its endorsement, recommendation, or favoring by the United States Government or any agency thereof. The views and opinions of authors expressed herein do not necessarily state or reflect those of the United States Government or any agency thereof. 


\section{DISCLAIMER}

Portions of this document may be illegible in electronic image products. Images are produced from the best available original document. 


\section{LEG A L NOTICE}

This report was prepared as an account of Government sponsored work. Neither the United States, nor the Commission, nor any person acting on behalf of the Commission:

A. Makes any warranty or representation, expressed or implied, with respect to the accuracy, completeness, or usefulness of the information contained in this report, or that the use of any information, apparatus, method, or process disclosed in this report may not infringe privately owned rights; or

B. Assumes any liabilities with respect to the use of, or for damages resulting from the use of any information, apparatus, method, or process disclosed in this report.

As used in the above, "person acting on behalf of the Commission" includes any employee or contractor of the Commission, or employee of such contractor, to the extent that such employee or contractor of the Commission, or employee of such contractor prepares, disseminates, or provides access to, any information pursuant to his employment or contract with the Commission, or his employment with such contractor.

Printed in the United States of America

Available from

Clearinghouse for Ferieral Scientific and Tecluical Information National Bureau of Standards, U. S. Department of Commerce

Springfield, Virginia 22151

Price: Printed Copy $\$ 3.00$; Microfiche $\$ 0.65$ 


\title{
CESTI PRICES
}

н. $3.00: 65$

\section{A PULSE AMPLIFIER USING INTEGRATED CIRCUITS}

\author{
W. H. Tyree
}

\author{
THE DOW CHEMICAL COMPANY \\ ROCKY FLATS DIVISION \\ P. O. BOX 888 \\ GOLDEN, COLORADO 80401 \\ U. S. ATOMIC ENERGY COMMISSION \\ CONTRACT AT(29-1)-1106
}


RFP-964 
CON T E N T S

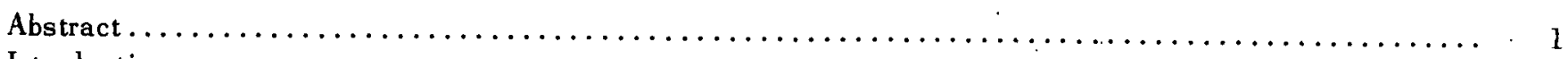

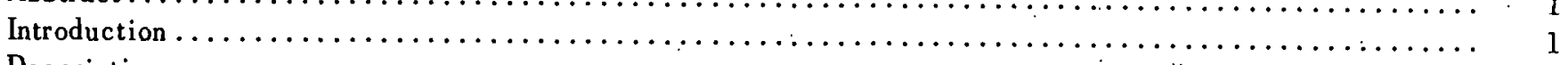

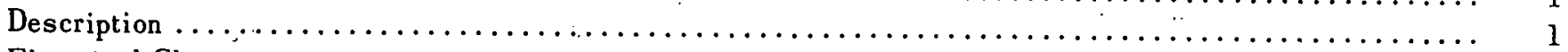

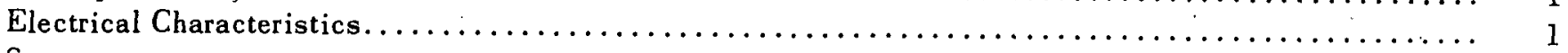

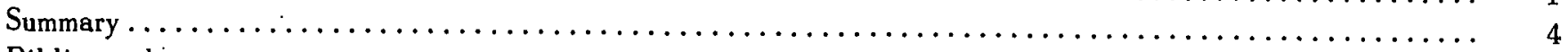

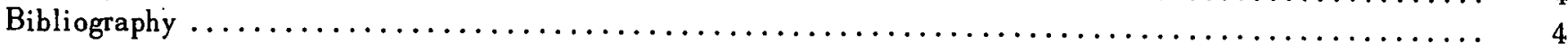

This report was prepared as an account of Government sponsored work. Nefther the United States, nor the Commission, nor any person acting on behalf of the Commission:

1 . i. of any infor privaloly owat ightor

privately owned righte; or use of Any

As used in the above, "person acting on behalf of the commission" includes any employee or contractor of the Commisaion, or employee of such contractor, to the extent that auch emplnyer or contractor of the Commission, or employee of such contractor prepares, disseminates, or provides access to, any Information pursuant 20 hls employment or contract with the Commisston, or his employment with such contractor

4




\section{A C K N OWL E D G M N T}

The author would like to thank Mr. C. W. Nordin for the printed circuit layout and construction of the amplifier described in this report. 


\section{A Pulse Amplifier Using Integrated Circuits}

\section{W. H. Tyree}

Abstract. A 0-10 volt pulse amplifier utilizing low cost linear and logic integrated circuits and plastic encased transistors was built. The unit had a maximum gain of 350 , noise input of 15 microvolts, adjustable risetime, and a coincident logic signal.

\section{INTRODUCTION}

Several companies have made available for industrial use medium gain, high frequency, linear integrated circuits. These are available for as low as $\$ 2.50$ per unit. The types of linear integrated circuits which were available through local electronic supply were compared for frequency response, gain, simplicity of installation, and unit cost. The Westinghouse Type WC-1146T was chosen for this application.

\section{DESCRIPTION}

The amplifier (Figure 1) was designed for use as a general purpose nuclear pulse amplifier. The input and output pulse levels and polarities conform to the guides set for the AEC module series. A logic signal (Figure 2) was included for use with a Nuclear Data ND-120 multichannel pulse height analyzer.

The amplifier circuit includes an 11 -step coursecontrol attenuator and a 10-turn wire-wound fine control attenuator at the input to the integrated circuit. The fine control allows a continuous adjustment of the voltage level with the maximum input voltage determined by the coarse control position. A pulse integrator control was connected to pin 7 of the integrated circuit for applications requiring optimum pulse shape. The output of the WC-1146T was taken as a negative pulse from pin 6 of the integrated circuit. An amplifier stage Q2 produced an output voltage swing capability of greater than 10 volts. An additional stage Q3 was included in the amplifier to decouple the amplifier output stage from a signal line and provide a low impedance driving oircuit for external equipment.

The linear signal was also used to produce a coincident pulse with a uniform pulse waveform. The emitter follower Q3 in the linear amplifier was connected to another emitter follower Q4 which has an output level control. A trigger amplifier Q5 was located between the emitter follower Q4 and the trigger circuit Q6 to improve the trigger sensitivity to low amplitude pulses from the amplifier. The pulse from the logic circuit Q6, a univibrator, was approximately 1.5 to 2 microseconds long. Emitter followers Q7 and Q8 were used to decouple the trigger circuit from the output logic lines.

\section{ELECTRICAL CHARACTERISTICS}

The amplifier linearity was tested over a wide range of input pulse amplitudes. The following curves demonstrated the overall linearity.

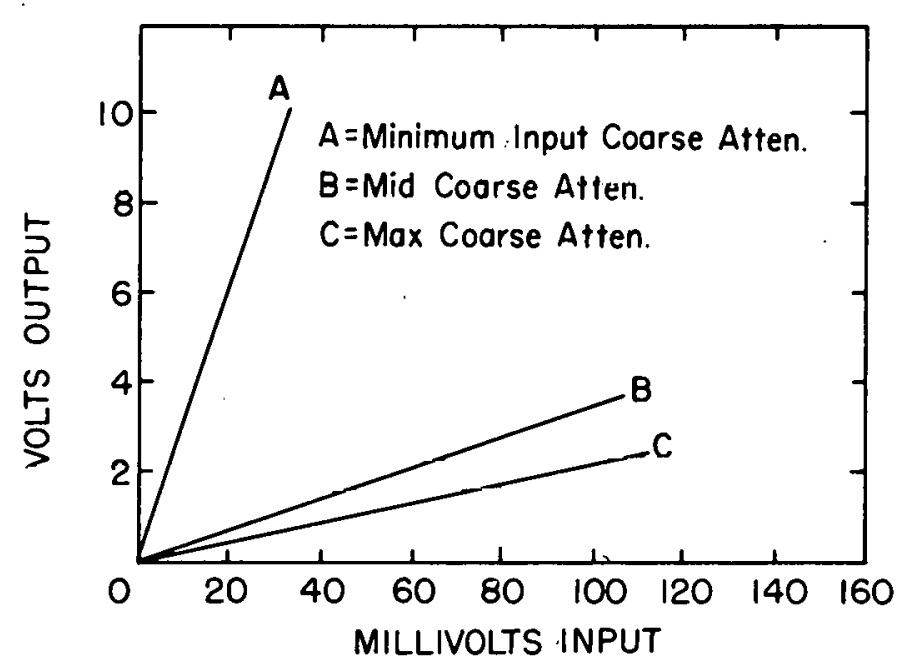

The noise output voltage from the amplifier with respect to the input is

$$
\text { E noise }=\frac{E \text { out }}{A}
$$

$$
\begin{aligned}
& \mathrm{A} \quad=330 \\
& \text { E out }=4 \times 10^{-3} \\
& \text { E noise }=15 \text { microvolts referred to the input. }
\end{aligned}
$$

The maximum gain of the amplifier was

$$
\mathrm{A}=\frac{\mathrm{E} \text { out }}{\mathrm{E} \text { in }}=350
$$




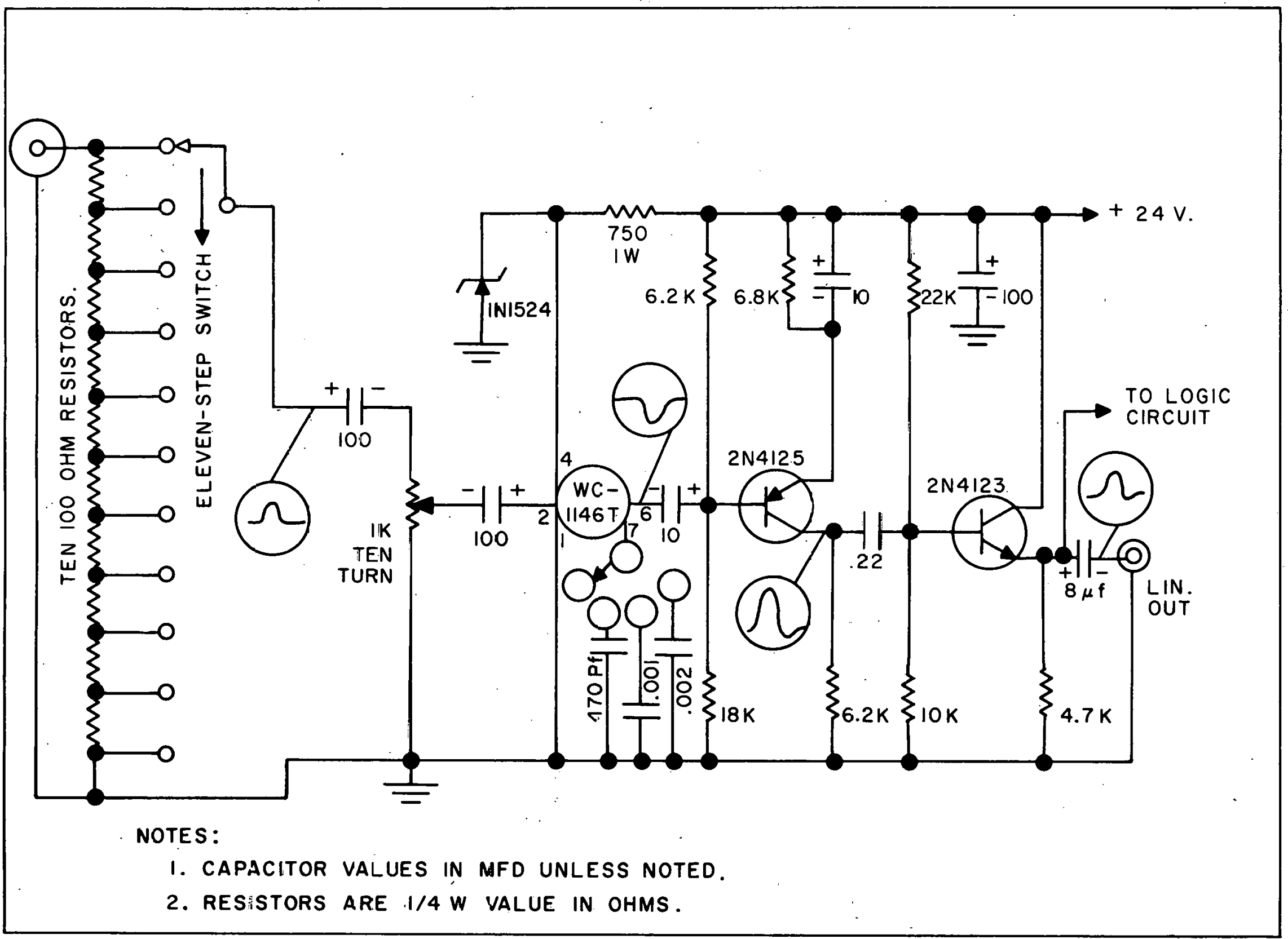




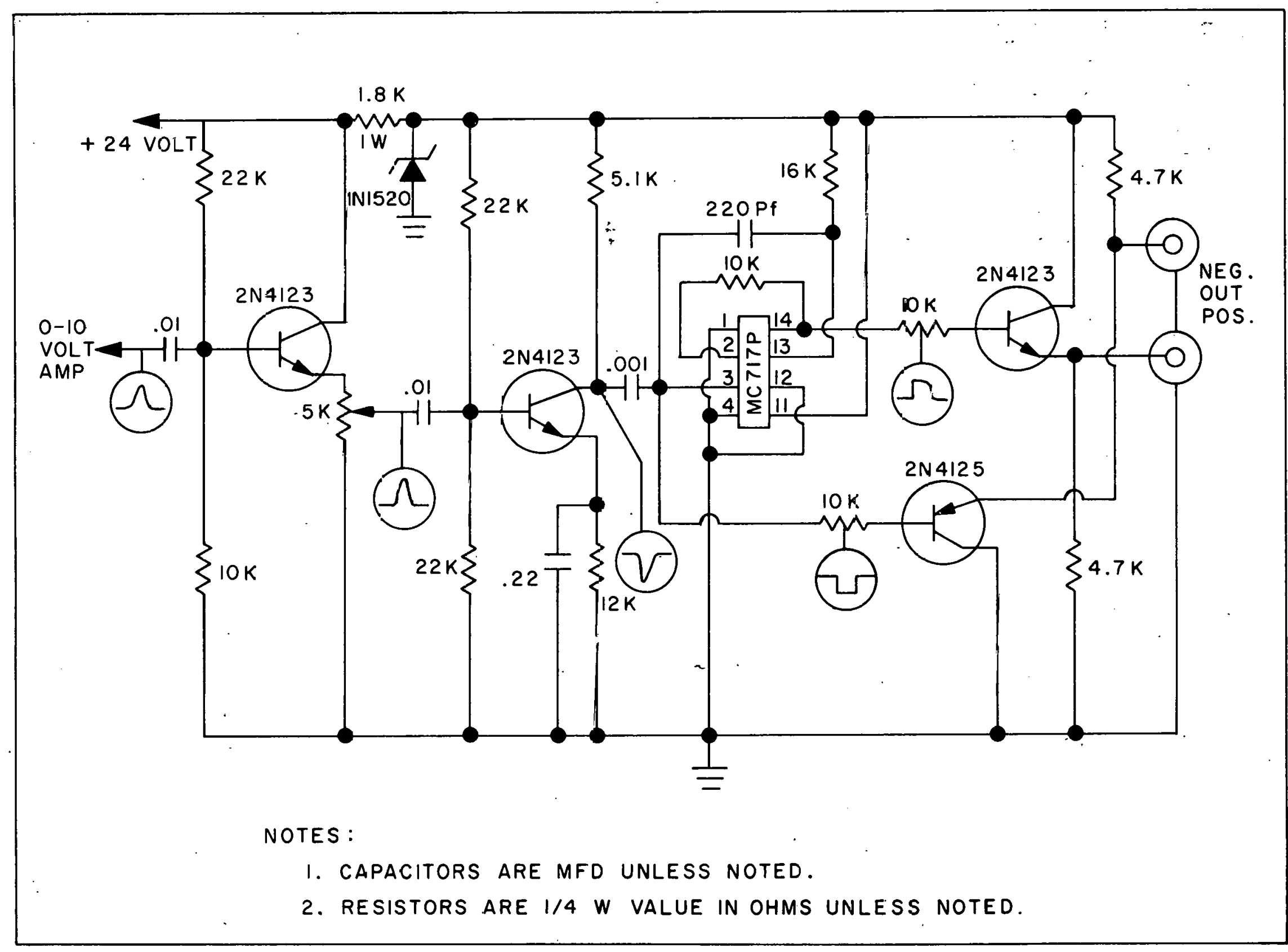




\section{SUMMARY}

A 0-10 volt amplifier which provides pulses for nuclear instrumentation was designed and built. The unit was housed in a single width AEC bin mounted module. The amplifier had a maximum. gain of 350 with an input noise level referred to the input of 15 microvolts.

The amplifier featured a $\$ 3.45$ linear integrated circuit and a $\$ 1.08$ plastic encased quad 2 input gate logic circuit.

\section{BIBLIOGRAPHY}

1. Westinghouse Electric Corporation. "Wide Band Amplifier Type WC-1146T." Technical Data Sheet No. 91-161. May 1966.

2. R. B. Hurley. "Junction Transistor Electronics." Third Printing. John Wiley and Sons, Inc. 1960.

3. Motorola Corporation. "MRTL Integrated Circuits Type MC717P." Technical Data Sheet. May 1966. 